\section{(C) OPEN ACCESS}

\title{
Methodical history taking may help in timely diagnosis of spontaneous intracranial hypotension
}

\author{
Jin Irie, ${ }^{1}$ Kensuke Shiga ${ }^{2}$
}

${ }^{1}$ Emergency and Critical Care, Tsugaru Health Coop Kensei Hospital, Hirosaki, Japan ${ }^{2}$ Neurology, Matsushita Memorial Hospital, Moriguchi, Japan

Correspondence to Dr Jin Irie,

jin-irie@koto.kpu-m.ac.jp

Accepted 13 July 2019
Check for updates

(c) BMJ Publishing Group Limited 2019. Re-use permitted under CC BY-NC. No commercial re-use. See rights and permissions. Published by BMJ.

To cite: Irie J, Shiga K. BMJ Case Rep 2019;12:e229103. doi:10.1136/bcr-2018-

229103

\section{SUMMARY}

Orthostatic headache $(\mathrm{OH})$ is a key symptom of spontaneous intracranial hypotension (SIH). However, there is no optimal history taking for $\mathrm{OH}$. A 35-year-old man complained of headache that prevented him from performing routine physical activities, which was relieved on lying down. We initially considered migraine as the most likely diagnosis. However, detailed history taking revealed that his headache worsened on standing, and he was finally diagnosed with $\mathrm{SIH}$. Headache relief on lying down is not a specific indicator of $\mathrm{OH}$ associated with $\mathrm{SIH}$. Thus, with regard to headache history taking, we suggest it important to confirm headache aggravation on standing.

\section{BACKGROUND}

Spontaneous intracranial hypotension $(\mathrm{SIH})$ is a rare cause of headache. However, it should be considered in the differential diagnosis of cases of new daily persistent headache because a good outcome can be achieved with appropriate treatments, such as bed rest and epidural self-blood patch therapy. ${ }^{1}$ Although orthostatic headache $(\mathrm{OH})$ is not included in the SIH diagnostic criteria of the International Classification of Headache Disorders 3rd edition (ICHD-3), it is a useful indicator of SIH because other symptoms, such as nausea and tinnitus, are non-specific. ${ }^{2}$ Thus, it is important to take a proper history of this headache for the diagnosis of SIH.

We herein report the case of a patient with $\mathrm{SIH}$ who had a delayed diagnosis because we did not identify the patient's feeling of headache relief on lying down as $\mathrm{OH}$.

\section{CASE PRESENTATION}

A 35-year-old man presented to our hospital with worsening of his headache pattern over the last 38 days. He had intermittent and non-pulsatile headache with nausea on every day. The duration of his headache was about $4-8$ hours. He had a medical history of migraine since around the age of 20 years and experienced his first headache at 15 years of age. Therefore, he could not state whether the present headache was similar to the previous headaches. He denied any recent history of head trauma. On physical examination, no remarkable findings were noted, including vital signs and neurology findings.

Initially, we suspected a relapse of migraine because he complained that he could not work owing to headache with nausea and that the headache was relieved by lying down. Non-steroidal anti-inflammatory drugs and triptan were prescribed, but they were ineffective. Forty-two days after onset, he was referred to an otorhinolaryngologist at another hospital for his complaint of tinnitus and was found to have mild sensorineural hearing loss on both sides. Because his headache worsened further, he was admitted to our hospital 54 days after onset.

On admission, detailed medical history revealed that his headache reduced $30 \mathrm{~min}$ after resting on a bed and worsened within $10 \mathrm{~min}$ of standing.

\section{INVESTIGATIONS}

CT showed chronic subdural haematomas (CSHs) on both sides, and gadolinium-enhanced MRI showed an enhancement of the pachymeninges, engorgement of venous structures and ventricular collapse (figure 1). Based on these findings, we diagnosed SIH with bilateral CSHs.

\section{TREATMENT}

After admission, we instructed him to take bed rest in the recumbent position and carefully monitored his neurological symptoms and imaging findings. His headache temporarily worsened and haematoma increased (figure 2), but his condition gradually improved, and he was discharged on day 69 after admission (day 124 after onset).

\section{OUTCOME AND FOLLOW-UP}

He returned to work without any symptoms 1 month after discharge, and MRI on day 219 after onset revealed that the CSHs almost disappeared.

\section{DISCUSSION}

Headache associated with SIH is caused by spontaneous spinal cerebrospinal fluid (CSF) leakage. ${ }^{2}$ The cause of CSF leakage remains largely unknown, but an underlying structural weakness of the spinal meninges, which is associated with connective tissue disorders such as Marfan syndrome, has been suspected. ${ }^{1}$ However, our patient did not have any finding of such diseases. Previous reports have reported cases associated with minor trauma or exercise. $^{3-6}$

In many cases of SIH, a conservative approach such as bed rest and oral hydration is effective and in severe case, the injection of autologous blood into the spinal epidural space (epidural blood patch) is the mainstay treatment. ${ }^{1}$ In a severe case of $\mathrm{CSH}$, surgical therapy is recommended. However, in case of SIH with CSH, the optimal treatment is controversial. ${ }^{7}$ In this case, we first tried conservative treatment for SIH and haematoma increased. Because his symptoms gradually improved, we 

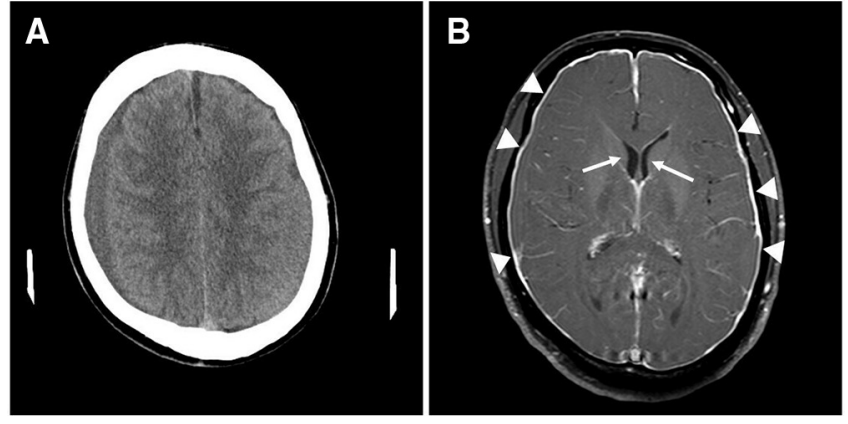

Figure 1 (A) Head CT on day 54 after onset showing chronic subdural haematomas on both sides. (B) Gadolinium-enhanced MRI on the same day showing findings of spontaneous intracranial hypotension, including an enhancement of the pachymeninges (arrowheads) and ventricular collapse (arrows).

continued conservative therapy. As a result, he got a better without epidural blood patch and surgery.

Epidemiology data regarding SIH are limited, but Schievink has reported its peak incidence at around 40 years of age. ${ }^{1}$ MRI is important for diagnosis of SIH. The five characteristic MRI features of SIH include (1) subdural fluid collection, (2) enhancement of the pachymeninges, (3) engorgement of venous structures, (4) pituitary hyperemia and (5) sagging of the brain. ${ }^{1}$ Subdural fluid collection is observed in $\sim 50 \%$ of SIH cases ${ }^{8}$ and enhancement of the pachymeninges in $83 \% .^{3}$

ICHD-3 has presented the following SIH diagnostic criteria: (A) headache fulfilling criterion $\mathrm{C}$ below, (B) absence of a procedure or trauma known to be able to cause CSF leakage, (C) headache has developed in temporal relation to occurrence of low CSF pressure or CSF leakage, or has led to its discovery, and (D) not better accounted for by another ICHD-3 diagnosis. ${ }^{2}$ Previously, SIH diagnostic criteria (ICHD-2) included $\mathrm{OH}$, which is diffuse and/or dull headache that worsens within $15 \mathrm{~min}$ after sitting or standing. ${ }^{9}$ But in some patients, this lag period may be prolonged to several hours. Therefore, ICHD-3 describes the usefulness of $\mathrm{OH}$ but its diagnostic criteria do not include it. Chung et al reported that almost all $\mathrm{SIH}$ patients have $\mathrm{OH}$ and that other symptoms include nausea (53\%), dizziness (30\%), neck stiffness (17\%), plugged ear (20\%) and tinnitus (20\%). Because these symptoms are non-specific, patients with SIH are commonly misdiagnosed, which results in a diagnostic delay. ${ }^{10}$ Therefore, it is important to take a proper history of $\mathrm{OH}$.
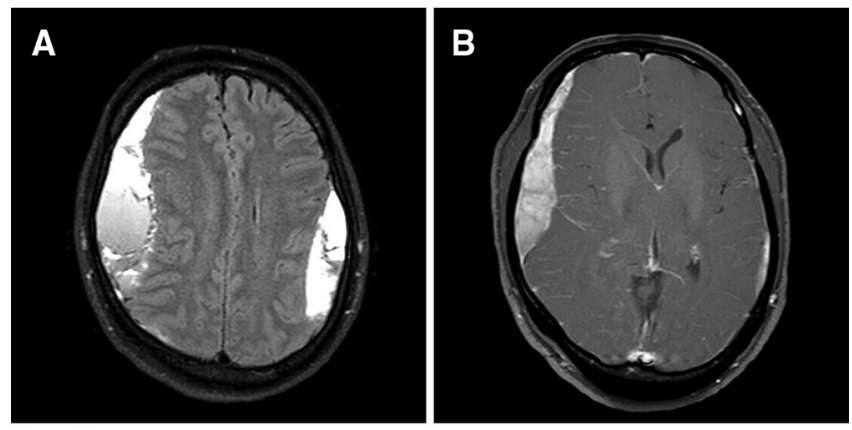

Figure 2 MRI on day 79 after onset. (A) Fluid-attenuated inversion recovery showing increasing chronic subdural haematomas on both sides. (B) T1-weighted views after intravenous administration of gadolinium showing a decreased enhancement of the pachymeninges.
In the present case, at the initial history taking, the patient mentioned that he could not work owing to headache and that the headache was relieved by lying down. We recognised it as a characteristic of migraine that is aggravated on activity and causes an avoidance of routine physical activity and thus, misdiagnosed the patient with migraine. After 2 weeks, further history taking indicated $\mathrm{OH}$ because his headache recurred within $10 \mathrm{~min}$ after rising from the recumbent position.

On taking medical history, $\mathrm{OH}$ is suspected if a patient's headache is relieved on lying down and aggravated on standing. However, in several diseases, patients experience headache relief on lying down. Therefore, only headache relief on lying down may indicate common causes of headache, such as migraine and tension, rather than $\mathrm{SIH}$.

Because $\mathrm{OH}$ associated with $\mathrm{SIH}$ may show a delayed response to postural change, with worsening after minutes or hours on standing and improvement after minutes or hours on lying down, ${ }^{23}$ an optimal history taking of $\mathrm{OH}$ has not been reported. In the present case, if headache aggravation on standing would have been identified at the initial assessment, then the condition may have been diagnosed earlier.

We herein reported a patient with $\mathrm{SIH}$ who had a delayed diagnosis because we did not identify the patient's feeling of headache relief on lying down as $\mathrm{OH}$. With regard to headache history taking for the diagnosis of SIH, we suggest that it is important to confirm not only headache relief on lying down but also headache aggravation on standing.

\section{Learning points}

- Headache which is new onset and aggravation is suggested secondary headache.

- Headache relief on lying down is not specific to spontaneous intracranial hypotension.

- In history taking of orthostatic headache, it is important to confirm headache aggravation on standing.

Acknowledgements $J$, the corresponding author, is the patient in the presented case. He would like to thank Dr T Kawabe who is the neurosurgeon of Kyoto Prefectural University of Medicine. He also thank all Neurosurgical ward staff of University Hospital, Kyoto Prefectural University of Medicine.

Contributors $\mathrm{J}$ designed the study and wrote the initial draft of the manuscript. KS critically reviewed the manuscript.

Funding The authors have not declared a specific grant for this research from any funding agency in the public, commercial or not-for-profit sectors.

Competing interests None declared.

Patient consent for publication Obtained.

Provenance and peer review Not commissioned; externally peer reviewed.

Open access This is an open access article distributed in accordance with the Creative Commons Attribution Non Commercial (CC BY-NC 4.0) license, which permits others to distribute, remix, adapt, build upon this work non-commercially, and license their derivative works on different terms, provided the original work is properly cited and the use is non-commercial. See: http://creativecommons.org/ licenses/by-nc/4.0/

\section{REFERENCES}

1 Schievink WI. Spontaneous spinal cerebrospinal fluid leaks and intracranial hypotension. JAMA 2006;295:2286-96.

2 Headache Classification Committee of the International Headache Society. The international classification of headache disorders, 3rd edition. Cephalalgia 2018;38:1-211.

3 Chung SJ, Kim JS, Lee MC. Syndrome of cerebral spinal fluid hypovolemia: clinical and imaging features and outcome. Neurology 2000;55:1321-7.

4 Grimaldi D, Mea E, Chiapparini L, et al. Spontaneous low cerebrospinal pressure: a mini review. Neurol Sci 2004;25:s135-s137. 
5 Murakami M, Morikawa K, Matsuno A, et al. Spontaneous intracranial hypotension associated with bilateral chronic subdural hematomas--case report. Neurol Med Chir 2000;40:484-8.

6 Toda S, Kitamura T, Teramoto A. A case of bilateral chronic subdural hematomas due to spontaneous intracranial hypotension. Nihon Ika Daigaku Igakkai Zasshi 2008:4:36-40.

7 Takahashi K, Mima T, Akiba Y. Chronic subdural hematoma associated with spontaneous intracranial hypotension: therapeutic strategies and outcomes of 55 cases. Neurol Med Chir 2016;56:69-76.
8 Schievink WI, Maya MM, Moser FG, et al. Spectrum of subdural fluid collections in spontaneous intracranial hypotension. J Neurosurg 2005;103:608-13.

9 Headache Classification Subcommittee of the International Headache Society. The international classification of headache disorders, 2nd edition. Cephalalgia 2004;24:1-160.

10 Schievink WI. Misdiagnosis of spontaneous intracranial hypotension. Arch Neurol 2003;60:1713-8.

Copyright 2019 BMJ Publishing Group. All rights reserved. For permission to reuse any of this content visit

https://www.bmj.com/company/products-services/rights-and-licensing/permissions/

BMJ Case Report Fellows may re-use this article for personal use and teaching without any further permission.

Become a Fellow of BMJ Case Reports today and you can:

- Submit as many cases as you like

- Enjoy fast sympathetic peer review and rapid publication of accepted articles

- Access all the published articles

- Re-use any of the published material for personal use and teaching without further permission

\section{Customer Service}

If you have any further queries about your subscription, please contact our customer services team on +44 (0) 2071111105 or via email at support@bmj.com.

Visit casereports.bmj.com for more articles like this and to become a Fellow 